\title{
Chapter 9 \\ Laboratory Diagnosis of Novel Coronavirus Disease 2019 (COVID-19) Infection
}

\author{
Abhishek Padhi, Swatantra Kumar, Ekta Gupta, \\ and Shailendra K. Saxena
}

\begin{abstract}
Coronavirus disease 2019 (COVID-19) is an infection caused by the novel coronavirus severe acute respiratory coronavirus 2 (SARS-CoV-2). The infection manifests as a mild flu to severe acute respiratory infection. The World Health Organization (WHO) declared COVID-19 as a global pandemic on March 11, 2020. The disease spreads by droplet infection from person to person. Early diagnosis is the key for prompt management of cases and control of the spread of the virus. Currently, the laboratory diagnosis of SARS-CoV-2 is based on nucleic acid amplification tests (NAAT) like real-time reverse transcriptase (RT-PCR). Various genes like E, N, S, ORF and RdRp are targeted as a part of screening and confirmation of cases. Furthermore, nucleic acid sequencing may be done for the identification of mutation in the genome of SARS-CoV-2. The development of serological assays and point of care molecular test will further intensify the diagnostic modalities of SARS-CoV-2.
\end{abstract}

Keywords COVID-19 $\cdot$ SARS-CoV-2 $\cdot$ Laboratory diagnosis $\cdot$ Molecular method

\subsection{Introduction}

Coronavirus disease 2019 (COVID-19) is a severe acute respiratory infection caused by the novel coronavirus severe acute respiratory syndrome coronavirus 2 (SARSCoV-2) (WHO 2020a), which started initially as a cluster of cases from Wuhan,

Abhishek Padhi and Shailendra K. Saxena contributed equally as first author.

\footnotetext{
A. Padhi · E. Gupta $(\bowtie)$

Department of Clinical Virology, Institute of Liver and Biliary Sciences, New Delhi, India

S. Kumar · S. K. Saxena

Centre for Advanced Research (CFAR), Faculty of Medicine, King George's Medical

University (KGMU), Lucknow, India

e-mail: shailen@kgmcindia.edu
}

(C) The Editor(s) (if applicable) and The Author(s), under exclusive licence to 
China (Zhu et al. 2020), has now spread to 135 countries with 142,539 number of confirmed cases and 5393 deaths (WHO 2020b). The World Health Organization declared COVID-19 as a global pandemic on March 11, 2020 (WHO 2020c). The disease primarily spreads via close contact of respiratory droplets generated by infected individuals (Center for Disease Control and Prevention 2020a). At the global level, sufficient testing capacity for COVID-19 is not available as it should be and therefore preventing individuals from accessing care. During the initial outbreak period, different countries have followed and implemented various testing strategies, depending on the availability of diagnostics and consumables. However, strict steps taken by the WHO has made the diagnostic available with the mission to "detect, protect and treat" to break the chain of transmission of SARS-CoV-2 (WHO 2020d). Therefore, early diagnosis and prompt treatment can substantially reduce the number of prospective cases. Hence, laboratory diagnosis of SARS-CoV-2 holds the key in containing and restricting the COVID-19 pandemic.

People who are in close contact with suspicious exposure have been advised under a 14-day health observation period that should be started from the last day of contact with infected individuals. Once these individuals show any symptoms including coughing, sneezing, shortness of breath or diarrhoea, they should require immediate medical attention. Immediate isolation of the suspected individual should be performed with proper guidelines, and they should be closely monitored for clinical symptoms and diagnosis should be performed in hospital-based laboratories as soon as possible. In addition, surveillance should be performed for those who were in contact with the suspected or conformed individuals by observing their clinical symptoms. Before taking decision about isolation, authorities should make sure that whether the suspected individual requires home isolation and careful clinical evaluation with safety assessment by healthcare professionals or not. If the suspected individuals present any symptoms during isolation, they should contact the doctors for their treatment. During home isolation, suggested medication and symptoms should be closely recorded. The suspected, probable and confirmed case definition of COVID-19 by the WHO has been presented in Fig. 9.1. The decision for diagnosis of an individual should be based on epidemiological and clinical factors which linked to an assessment of the probability of infection.

\subsection{Specimen Types and Collection}

Adequate standard operating procedures (SOPs) should be followed before collecting any specimen, including the accurate training of the staff for appropriate specimen collection, packaging, storage and transport. The staff should be very well aware of the preventive measures and control guidelines for COVID-19, for that purpose WHO interim guidance should be followed. Collected specimens should be regarded as potentially infectious and therefore extreme precautions should be taken during the handling of the samples. The diagnosis of clinical specimens collected from the suspected individuals should be executed in appropriately equipped 


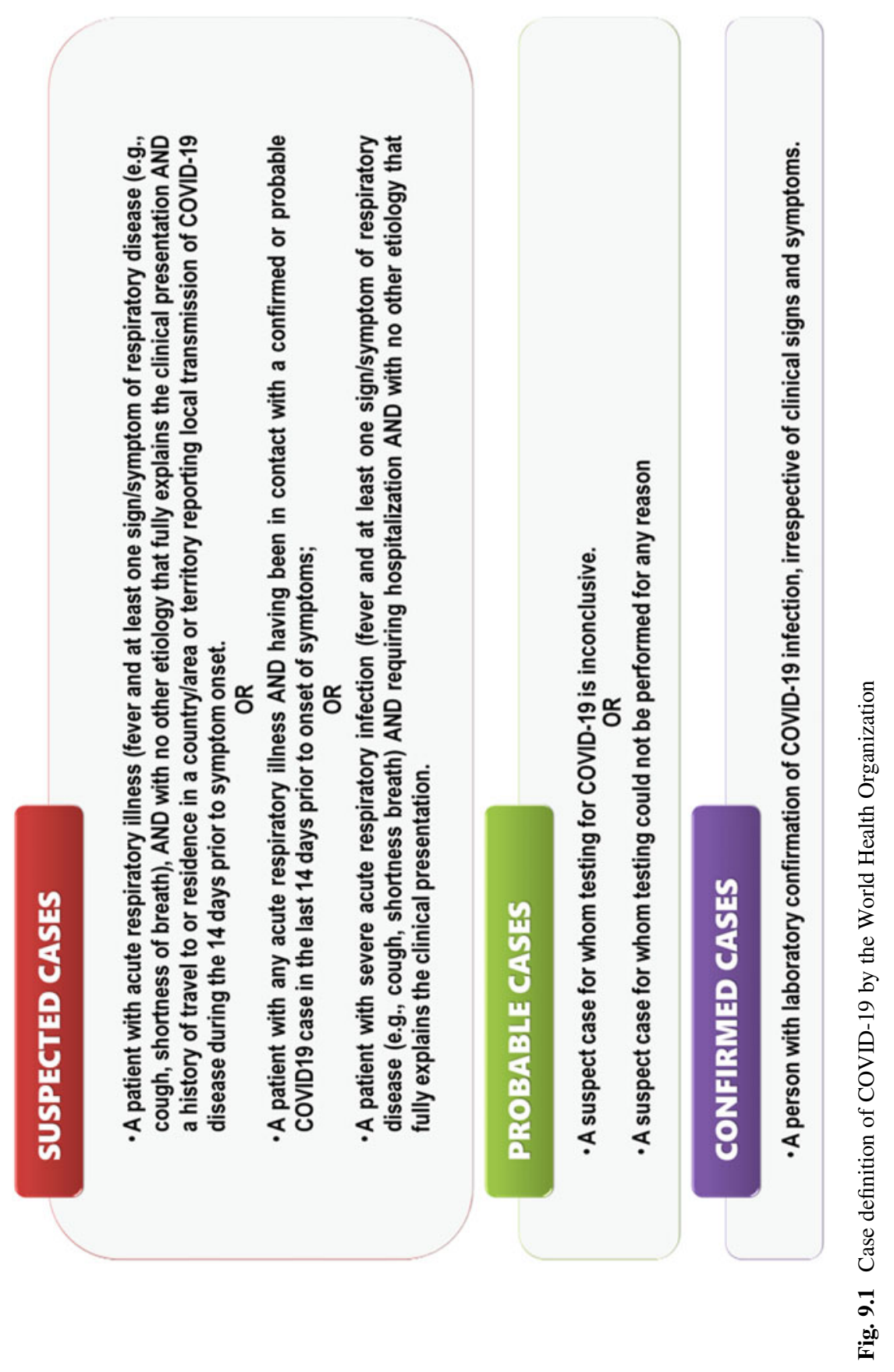


laboratories by the staff specifically trained in technical and biosafety measures. National guidelines on laboratory biosafety should be strictly followed, and all the procedures should be undertaken based on a risk assessment. Specimens for molecular diagnostics require BSL-2 or equivalent facilities, whereas any attempt to culture virus requires BSL-3 facilities at minimum. At least respiratory material should be collected for the diagnosis of COVID-19 from suspected individuals. Upper respiratory tract specimens nasopharyngeal and oropharyngeal swab or wash in ambulatory patients including lower respiratory specimens such as sputum (if generated) and/or bronchoalveolar lavage or endotracheal aspirate in patients with more severe respiratory disease (WHO 2020e). Other clinical samples may also be collected as SARS-CoV-2 has also been found in blood and stool, similar to SARS and MERS (Wu et al. 2020). In addition, paired sera should be collected during acute and convalescent phase for retrospective study using serological assays (when available). For post-mortem study, lung tissue may be collected for studying the pathophysiology of the disease. Specimen collection details proposed by the WHO have been presented in Table 9.1.

\subsection{Biosafety Measures}

Samples should be collected by well-trained healthcare personnel, donning proper personal protective equipment (PPE) which includes masks, gloves, goggles, gown, head cover, shoe cover and hand sanitizer, soap and water following adequate infection control measures including hand hygiene and adequate biosafety precautions to protect individual and the environment (Center for Disease Control and Prevention 2020b).

The correct sequence of donning the PPE:

- Home clothes, jewellery, watches, rings, bangles, etc. should be removed and hospital scrub suite should be donned.

- Proper hand hygiene to be done using alcohol-based hand rub or soap and water prior to donning of the PPE.

- Sequence of donning PPE: Shoe cover $\rightarrow$ clean, disposable non-permeable gown $\rightarrow$ N95 respirator with proper fit testing $\rightarrow$ Eye goggles/face shield $\rightarrow$ Head cover $\rightarrow$ Gloves.

The correct sequence of doffing the PPE:

- Doffing should be done only in designated areas.

- Any soiling in the PPE must be checked before doffing. If any, the area should be disinfected before doffing.

- Hand hygiene must be followed after every step.

- Sequence of doffing the PPE: Shoe cover $\rightarrow$ Gloves $\rightarrow$ Eye goggles/face shield $\rightarrow$ Head cover $\rightarrow$ Gown $\rightarrow$ N95 respirator. 
Table 9.1 Specimen collection details

\begin{tabular}{|c|c|c|c|c|}
\hline Specimen type & $\begin{array}{l}\text { Collection } \\
\text { materials }\end{array}$ & $\begin{array}{l}\text { Transport } \\
\text { to } \\
\text { laboratory }\end{array}$ & $\begin{array}{c}\text { Storage } \\
\text { temperature till } \\
\text { testing }\end{array}$ & Comments \\
\hline $\begin{array}{l}\text { Nasopharyngeal and } \\
\text { oropharyngeal } \\
\text { swaba }\end{array}$ & $\begin{array}{l}\text { Dacron or } \\
\text { polyester flocked } \\
\text { swabs }^{b}\end{array}$ & $4^{\circ} \mathrm{C}$ & $\begin{array}{l}\leq 5 \text { days }: 4^{\circ} \mathrm{C} \\
>5 \text { days : }-70^{\circ} \mathrm{C}\end{array}$ & $\begin{array}{l}\text { To increase the viral load both } \\
\text { nasopharyngeal and oropharyngeal } \\
\text { swabs should be placed in the same } \\
\text { tube }\end{array}$ \\
\hline $\begin{array}{l}\text { Bronchoalveolar } \\
\text { lavage }\end{array}$ & Sterile container ${ }^{b}$ & $4^{\circ} \mathrm{C}$ & $\begin{array}{l}\leq 48 \text { hours : } 4^{\circ} \mathrm{C} \\
>48 \text { hours: }-70^{\circ} \mathrm{C}\end{array}$ & $\begin{array}{l}\text { Some dilution of pathogen may be } \\
\text { there but a important specimen in } \\
\text { patients with serious infection }\end{array}$ \\
\hline $\begin{array}{l}\text { Tracheal aspirate, } \\
\text { nasopharyngeal } \\
\text { aspirate or nasal } \\
\text { wash }\end{array}$ & Sterile container $^{\mathrm{b}}$ & $4^{\circ} \mathrm{C}$ & $\begin{array}{l}\leq 48 \text { hours : } 4^{\circ} \mathrm{C} \\
>48 \text { hours: }-70^{\circ} \mathrm{C}\end{array}$ & - \\
\hline Sputum & Sterile container & $4^{\circ} \mathrm{C}$ & $\begin{array}{l}\leq 48 \text { hours : } 4^{\circ} \mathrm{C} \\
>48 \text { hours: }-70^{\circ} \mathrm{C}\end{array}$ & $\begin{array}{l}\text { To ensure if the material is from } \\
\text { lower respiratory tract }\end{array}$ \\
\hline $\begin{array}{l}\text { Tissue from biopsy } \\
\text { or autopsy including } \\
\text { from lung }\end{array}$ & $\begin{array}{l}\text { Sterile container } \\
\text { with saline or } \\
\text { VTM }\end{array}$ & $4^{\circ} \mathrm{C}$ & $\begin{array}{l}\leq 24 \text { hours: } 4^{\circ} \mathrm{C} \\
>24 \text { hours: }-70^{\circ} \mathrm{C}\end{array}$ & $\begin{array}{l}\text { Important for post mortem } \\
\text { diagnosis }\end{array}$ \\
\hline $\begin{array}{l}\text { Serum (acute and } \\
\text { convalescent } \\
\text { samples) }\end{array}$ & $\begin{array}{l}\text { Serum separator } \\
\text { tubes (adults: } \\
\text { collect 3-5 ml } \\
\text { whole blood) }\end{array}$ & $4^{\circ} \mathrm{C}$ & $\begin{array}{l}\leq 5 \text { days }: 4^{\circ} \mathrm{C} \\
>5 \text { days : }-70^{\circ} \mathrm{C}\end{array}$ & $\begin{array}{l}\text { Paired samples to be collected : } \\
\text { Acute }- \text { first week of illness } \\
\text { Chronic }-2 \text { to } 3 \text { weeks later }\end{array}$ \\
\hline Whole blood (5ml) & Blood in EDTA vial & $4^{\circ} \mathrm{C}$ & $\begin{array}{l}\leq 5 \text { days }: 4^{\circ} \mathrm{C} \\
>5 \text { days : }-70^{\circ} \mathrm{C}\end{array}$ & - \\
\hline Stool & Stool container & $4^{\circ} \mathrm{C}$ & $\begin{array}{l}\leq 5 \text { days }: 4^{\circ} \mathrm{C} \\
>5 \text { days : }-70^{\circ} \mathrm{C}\end{array}$ & $\begin{array}{l}\text { Important sample to rule out } \\
\text { gastrointestinal infection }\end{array}$ \\
\hline Urine & $\begin{array}{l}\text { Urine collection } \\
\text { container }\end{array}$ & $4^{\circ} \mathrm{C}$ & $\begin{array}{l}\leq 5 \text { days }: 4^{\circ} \mathrm{C} \\
>5 \text { days }:-70^{\circ} \mathrm{C}\end{array}$ & - \\
\hline
\end{tabular}

Adapted from the WHO guidelines

${ }^{\text {a }}$ Mandatory specimen, ${ }^{\mathrm{b}}$ for transport of samples, viral transport medium (VTM) is to be used containing antibiotics and antifungal

- All the PPE must be disinfected and discarded following the local biomedical waste management rules.

Steps for processing of samples:

- Initial processing (before inactivation) of all specimens should take place in a biological safety cabinet (BSC) or primary containment device (Center for Disease Control and Prevention 2020c).

- Laboratory work involving non-propagative methods (e.g. sequencing, nucleic acid amplification test [NAAT]) should be conducted in a Biosafety Level 2 (BSL-2) facility (Center for Disease Control and Prevention 2020c).

- Laboratory work involving propagative methods (e.g. virus culture, isolation or neutralization assays) should be conducted at a containment laboratory with 
inward directional airflow in a Biosafety Level-3 (BSL-3) facility (Center for Disease Control and Prevention 2020c).

- Disinfectants having action against enveloped viruses should be used (e.g. hypochlorite [bleach], alcohol, hydrogen peroxide, quaternary ammonium compounds and phenolic compounds) (Center for Disease Control and Prevention 2020c).

- Patient specimens from suspected or confirmed cases should be transported as UN3373, "Biological Substance Category B". Viral cultures or isolates should be transported as Category A, UN2814, "infectious substance, affecting humans" (Center for Disease Control and Prevention 2020c).

\subsection{Specimen Collection Packaging and Transport}

After the collection, specimens should be transported to the laboratory as soon as possible for the diagnosis of COVID-19. During the transportation of the specimens correct handling of the specimens is indispensable. Specimen transportation should be performed and shipped under the cold chain maintenance of $2-8{ }^{\circ} \mathrm{C}$. If in case of delay in delivery of the specimen to the laboratory, the specimens should be transported in a viral transport medium. It can be also frozen to $-20{ }^{\circ} \mathrm{C}$ or ideally $-70{ }^{\circ} \mathrm{C}$ and shipped on dry ice if further delays are likely to expect. During transportation, it is crucial to avoid repeated thawing and freezing of specimens. Transportation within national borders should comply with applicable rules and regulations. In case of international transportation of specimens, the UN Model Regulations should be followed along with other regulations depending on the mode of transport. The requirements for specimen collection, packaging and transport have been presented in Fig. 9.2 and the procedure for specimen packaging and transport has been presented in Fig. 9.3 (Center for Disease Control and Prevention 2020d). After specimen collection and packaging, the well-packed specimen (triple packaging as shown in Fig. 9.4) is shipped at the earliest to the nearest testing centre maintaining proper cold chain (WHO 2020f).
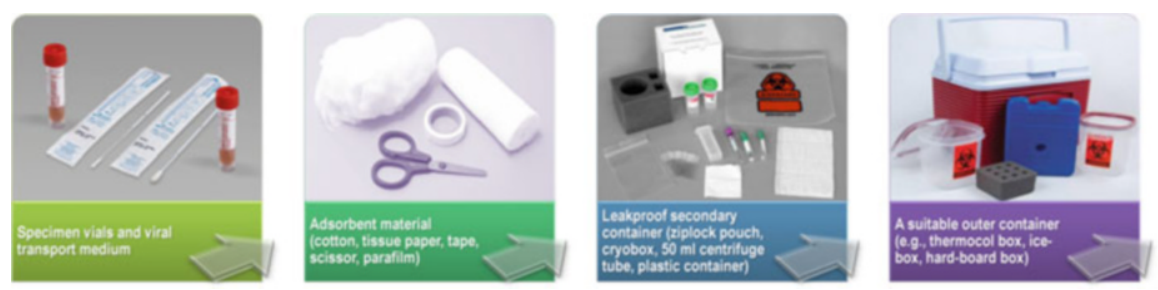

Fig. 9.2 Requirements for specimen collection, packaging and transport 


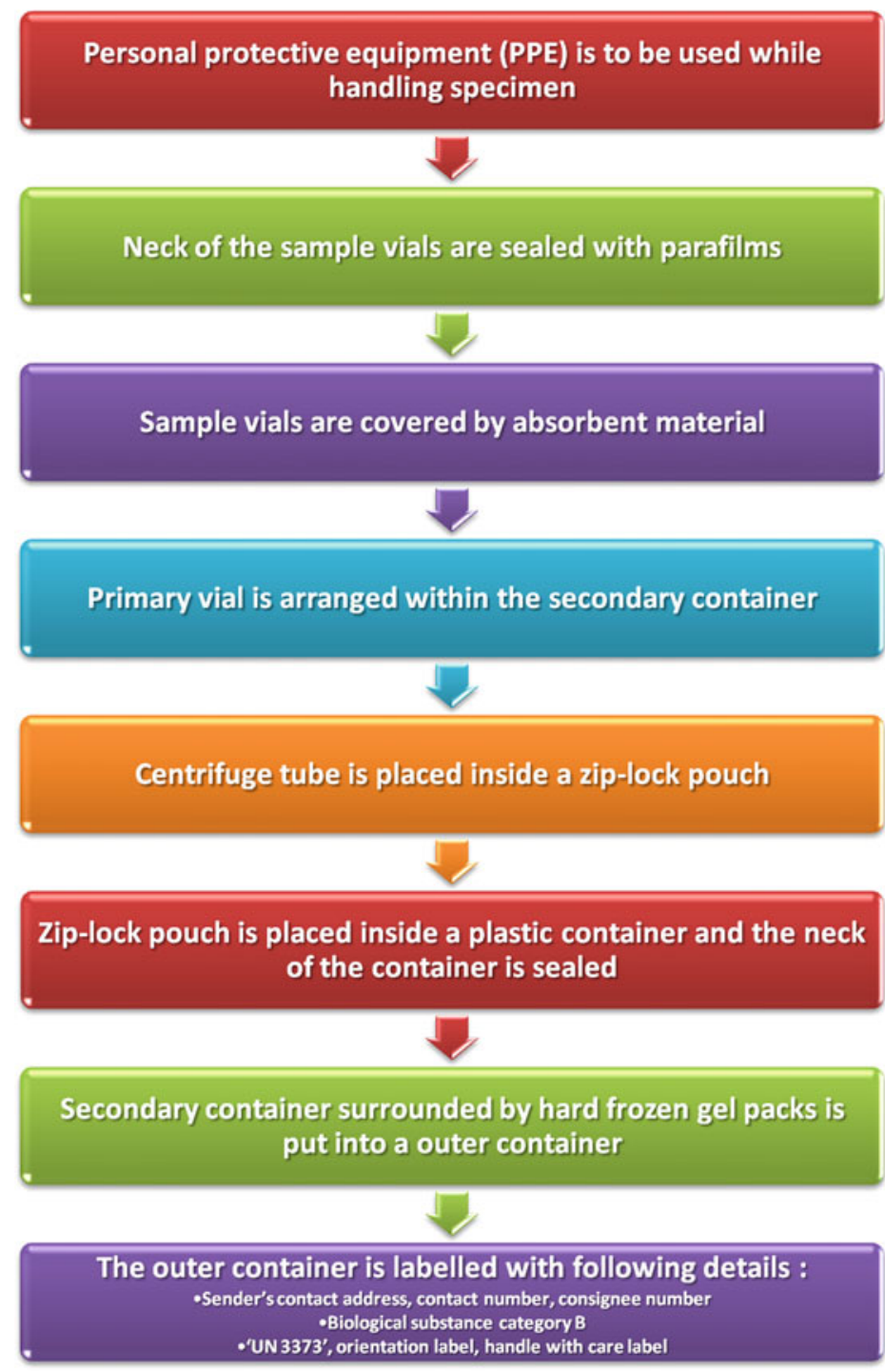

Fig. 9.3 Procedure for specimen packaging and transport

\subsection{Diagnostic Methods for the Detection of SARS-CoV-2}

\subsubsection{Nucleic Acid Amplification Testing (NAAT)}

At present confirmation of cases of COVID-19 is based on the detection of viral RNA by nucleic acid amplification tests (NAAT) such as real-time reverse transcriptase polymerase chain reactions (RT-PCR) with confirmation by nucleic acid 


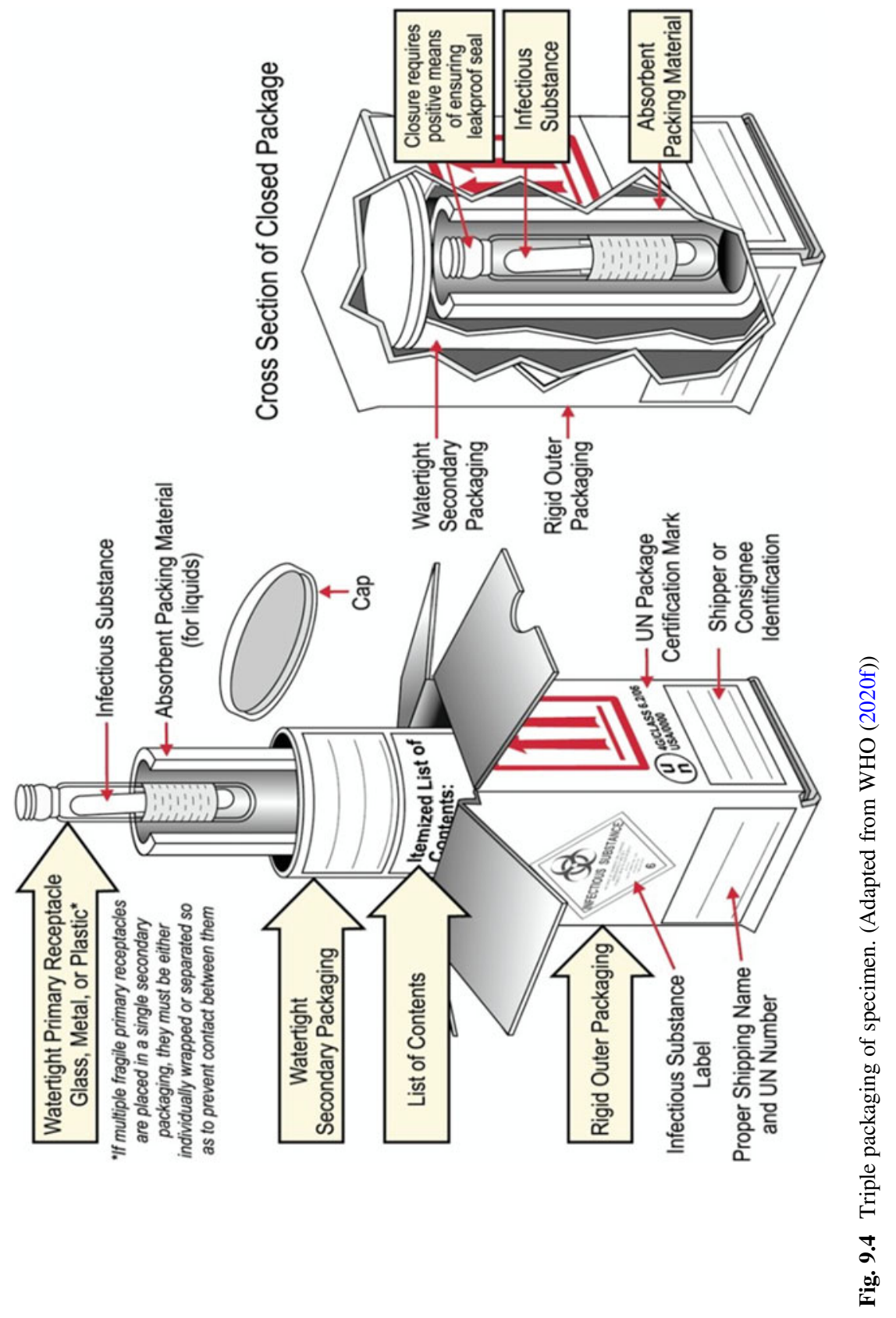




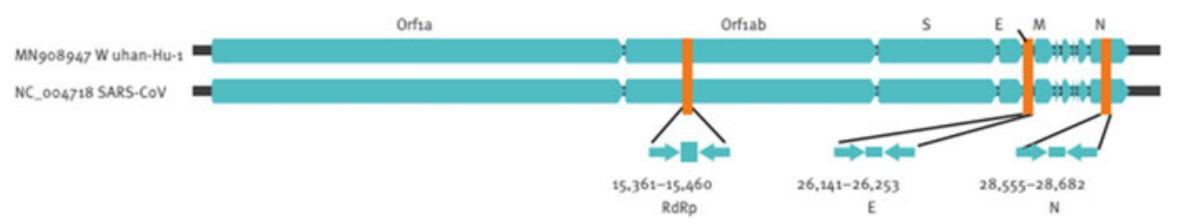

Fig. 9.5 Relative positions of amplicon targets on SARS-CoV-2 genome. ORF open reading frame, $R d R p$ RNA-dependent RNA polymerase, $E$ envelop protein gene, $N$ nucleocapsid protein gene, $M$ membrane protein gene, $S$ spike protein gene

Table 9.2 Currently available protocol

\begin{tabular}{l|l|l}
\hline Country & Institute & Gene targets \\
\hline China & China CDC & ORF 1ab and N \\
\hline Germany & Charitè & RdRp, E, N \\
\hline Hong Kong SAR & HKU & ORF 1b-nsp14, N \\
\hline Japan & $\begin{array}{l}\text { National Institute of Infectious Diseases, } \\
\text { Department of Virology }\end{array}$ & $\begin{array}{l}\text { Pancorona and multiple tar- } \\
\text { gets, spike protein }\end{array}$ \\
\hline Thailand & National Institute of Health & N \\
\hline USA & US CDC & Three targets in N gene \\
\hline France & Pasteur Institute, Paris & Two targets in RdRp gene \\
\hline
\end{tabular}

Adapted from WHO (2020e)

sequencing when necessary (WHO 2020e). The viral genes targeted so far include the N, E, S, ORF and RdRp genes (Fig. 9.5) according to SARS-CoV, GenBank NC_004718 (WHO 2020f). Different protocols followed by various countries are mentioned in Table 9.2.

One of the following conditions should be met to consider a case as laboratory confirmed by NAAT in areas with no SARS-CoV-2 circulation:

- A positive NAAT result for at least two different targets on the SARS-CoV-2 virus genome, of which at least one target is preferably specific for SARS-CoV-2 virus using a validated assay; OR

- One positive NAAT result for the presence of betacoronavirus, and SARS-CoV-2 virus further identified by sequencing partial or whole genome of the virus as long as the sequence target is larger or different from the amplicon probed in the NAAT assay used.

When there is ambiguity in results, sample should once again be collected from the patient and, if appropriate, sequencing of the virus from the original specimen or of an amplicon generated from an appropriate NAAT assay, different from the NAAT assay initially used, should be obtained to provide a reliable test result.

Areas where SARS-CoV-2 virus is widely circulating a simpler logarithm might suffice; for example screening of a single differential target is sufficient. One or more negative results do not rule out the possibility of SARS-CoV-2 virus infection. A number of factors could lead to a negative result in an infected individual, including: 
- Poor quality of the specimen, containing little patient material (as a control, consider determining whether there is adequate human DNA in the sample by including a human target in the PCR testing).

- The specimen was collected late or very early in the infection.

- The specimen was not handled and shipped appropriately (non-maintenance of cold chain).

- Technical reasons inherent in the test, e.g. virus mutation or PCR inhibition.

If a negative result is obtained from a patient with a high index of suspicion for SARS-CoV-2 virus infection, particularly when only upper respiratory tract specimens were collected, additional specimens, including from the lower respiratory tract if possible, should be collected and tested.

\subsubsection{Viral Sequencing}

Sequencing does not have a role in the initial laboratory diagnosis of SARS-CoV-2 but can be helpful in the following circumstances:

- Providing confirmation of the presence of the virus.

- Monitor for viral genome mutations that might affect the performance of medical countermeasures, including diagnostic tests.

- Virus whole genome sequencing can also inform molecular epidemiology studies.

\subsubsection{Serology}

- Can aid investigation of an ongoing outbreak and retrospective assessment of the attack rate or extent of an outbreak.

- In cases where NAAT assays are negative and there is a strong epidemiological link to COVID-19 infection, paired serum samples (in the acute and convalescent phase) might support diagnosis once validated serology tests are available. Serum samples can be stored for these purposes.

\subsubsection{Viral Culture}

Viral culture is not recommended for the laboratory diagnosis of SARS-CoV-2. But viral culture can be used for research purposes like isolation of the virus, studying the properties of the virus and development of vaccine. Human airway epithelial cell lines were used for the initial isolation of the virus (Zhu et al. 2020). 


\subsection{Challenges for Diagnosis}

Early diagnosis of COVID-19 is essential for the timely management as well as isolation of confirmed cases to prevent further transmission of patients. However, sample collection, transport and kit validation are major bottlenecks in the diagnosis of COVID-19. A study found that the total positivity of cases by initial RT-PCR were around 30-60\% (Ai et al. 2020). This largely depends on the time at which sample has been collected as PCR positivity will be seen during the early days of symptoms. Furthermore, the sensitivity of the testing kits is a matter of debate and thereby a sizeable number of patients may not be identified, which may ultimately be detrimental in the early diagnosis and treatment of COVID-19 cases. Also in lowand middle-income countries (LMIC) (Hopman et al. 2020), the healthcare system is not robust enough as a result of which the testing laboratories often face difficulties in the performance of molecular testing.

\section{Executive Summary}

- COVID-19

- Severe acute respiratory infection caused by novel coronavirus SARSCoV-2.

- First reported from Wuhan, China, as a cluster of cases with pneumonia.

- The WHO declared COVID-19 as a global pandemic on March $11,2019$.

- Sample types, collection and transport

- Vital samples: nasopharyngeal and oropharyngeal swabs collected in a single tube of viral transport media (VTM) to increase the yield of virus.

- Other samples: paired sera (acute and convalescent phase serum sample), blood, bronchoalveolar lavage.

- Sample packing to be done in a triple packing method and properly labelled.

- Sample processing should be done in a biosafety level-2 facility.

- Laboratory diagnosis

- Currently, laboratory diagnosis of SARS-CoV-2 is done by nucleic acid amplification testing like real-time reverse transcriptase PCR.

- The viral genes targeted so far include the N, E, S, ORF and RdRp genes.

- Various countries have submitted their primer probe designs to the WHO.

- Many countries are adapting two-stage protocol. 
- Example: for screening-E gene is targeted and for confirmationRdRp gene is targeted (Germany protocol).

- Sequencing partial or whole genome.

- Challenges in diagnosis

- Sample collection, transport and kit performance are major bottlenecks in the diagnosis of COVID-19.

- Availability of point of care tests which require minimal biosafety requirements.

\subsection{Conclusions}

Early diagnosis is the key for prompt management of COVID-19. Serological and molecular assays together will further strengthen the diagnosis of SARS-CoV-2. Laboratory networking is the need of the hour for real-time diagnosis of COVID-19.

\subsection{Future Perspectives}

Considering the above challenges for the diagnosis, a robust laboratory network is the need of the hour. India has a wide network of laboratories for testing of viral diseases; the Viral Research and Diagnostic Laboratories (VRDL) forms the base of the testing laboratories pyramid with an apex centre at the top of the pyramid. In these testing times, these VRDLs are taking the lead in the real-time diagnosis of COVID-19 in India. Such robust networking of laboratories can be replicated in LMICs for prompt sample collection till the final diagnosis of SARS-CoV-2 and other viral infections. Also the development of a serological assay at the earliest will be beneficial for resource-limited countries, and also the turnaround time will be significantly reduced. Furthermore, as the pandemic widens its arm a point of care molecular test will be like a holy grail in the rapid diagnosis of cases, thereby initiating the treatment at the earliest.

\section{References}

Ai T, Yang Z, Hou H, Zhan C, Chen C, Lv W, Tao Q, Sun Z, Xia L (2020) Correlation of chest CT and RT-PCR testing in coronavirus disease 2019 (COVID-19) in China: a report of 1014 cases. Radiology:200642. https://doi.org/10.1148/radiol.2020200642

Center for Disease Control and Prevention (2020a) Coronavirus disease 2019 (COVID-19) transmission. In: Center for Disease Control and Prevention. https://www.cdc.gov/coronavi rus/2019-ncov/prepare/transmission.html. Accessed 15 Mar 2020 
Center for Disease Control and Prevention (2020b) Interim infection prevention and control recommendations for patients with suspected or confirmed coronavirus disease 2019 (COVID-19) in healthcare settings. Centre for Disease Control and Prevention. https://www. cdc.gov/coronavirus/2019-ncov/infection-control/control-recommendations.html. Accessed 25 Mar 2020

Center for Disease Control and Prevention (2020c) Interim Laboratory Biosafety Guidelines for handling and processing specimens associated with coronavirus disease 2019 (COVID-19). Centre for Disease Control and Prevention. https://www.cdc.gov/coronavirus/2019-ncov/lab/ lab-biosafety-guidelines.html. Accessed 25 Mar 2020

Center for Disease Control and Prevention (2020d) Interim Guidelines for collecting, handling, and testing clinical specimens from persons for coronavirus disease 2019 (COVID-19). Centre for Disease Control and Prevention. https://www.cdc.gov/coronavirus/2019-ncov/lab/guidelinesclinical-specimens.html. Accessed 25 Mar 2020

Hopman J, Allegranzi B, Mehtar S (2020) Managing COVID-19 in low- and middle-income countries. JAMA. https://doi.org/10.1001/jama.2020.4169

WHO (2020a) Naming the coronavirus disease (COVID-19) and the virus that causes it. https:// www.who.int/emergencies/diseases/novel-coronavirus-2019/technical-guidance/naming-thecoronavirus-disease-(covid-2019)-and-the-virus-that-causes-it. Accessed 15 Mar 2020

WHO (2020b) Novel coronavirus (2019-nCoV) situation reports. https://www.who.int/emergen cies/diseases/novel-coronavirus-2019/situation-reports. Accessed 15 Mar 2020

WHO (2020c) WHO Director-General's opening remarks at the media briefing on COVID-19. https://www.who.int/dg/speeches/detail/who-director-general-s-opening-remarks-at-the-mediabriefing-on-covid-19\%2D\%2D-11-march-2020. Accessed 15 Mar 2020

WHO (2020d) WHO Director-General's opening remarks at the media briefing on COVID-19. https://www.who.int/dg/speeches/detail/who-director-general-s-opening-remarks-at-the-mis sion-briefing-on-covid-19\%2D\%2D-13-march-2020. Accessed 15 Mar 2020

WHO (2020e) Laboratory testing for 2019 novel coronavirus (2019-nCoV) in suspected human cases. https://www.who.int/publications-detail/laboratory-testing-for-2019-novel-coronavirusin-suspected-human-cases-20200117. Accessed 15 Mar 2020

WHO (2020f) Guidelines for the safe transport of infectious substances and diagnostic specimens. In: WHO. https://www.who.int/csr/resources/publications/biosafety/WHO_EMC_97_3_EN/ en/. Accessed 18 Mar 2020

Wu Y, Guo C, Tang L, Hong Z, Zhou J, Dong X, Yin H, Xiao Q, Tang Y, Qu X, Kuang L, Fang X, Mishra N, Lu J, Shan H, Jiang G, Huang X (2020. pii: S2468-1253(20) 30083-2) Prolonged presence of SARS-CoV-2 viral RNA in faecal samples. Lancet Gastroenterol Hepatol. https:// doi.org/10.1016/S2468-1253(20)30083-2

Zhu N, Zhang D, Wang W et al (2020) A novel coronavirus from patients with pneumonia in China, 2019. N Engl J Med 382:727-733 